\title{
Combination treatment with sorafenib and wh-4 additively suppresses the proliferation of liver cancer cells
}

\author{
SU-HONG CHEN ${ }^{1,2}$, DAN-DAN XU ${ }^{2}$, PENG-JUN ZHOU ${ }^{1}$, YAO WANG ${ }^{1}$, QIU-YING LIU ${ }^{1}$, ZHE REN $^{1}$, \\ ZHONG LIU ${ }^{1}$, XIA WANG ${ }^{2}$, HUI-QING HUANG ${ }^{2}$, XUE XUE $^{2}$, YING WANG ${ }^{3}$ and YI-FEI WANG ${ }^{1}$ \\ ${ }^{1}$ College of Life Science and Technology, Jinan University, Guangzhou, Guangdong 510632; ${ }^{2}$ College of Biotechnology, \\ Guangdong Food and Drug Vocational College, Guangzhou, Guangdong 510520; ${ }^{3}$ College of Food Science and Technology, \\ Zhongkai University of Agriculture and Engineering, Guangzhou, Guangdong 510225, P.R. China
}

Received March 24, 2020; Accepted December 6, 2021

DOI: $10.3892 /$ etm.2022.11156

\begin{abstract}
Sorafenib is currently used to treat hepatocellular carcinoma (HCC). However, the development of chemoresistance to sorafenib is a major limitation for sorafenib-based therapy in patients with HCC. In the present study, the effect of the combination therapy of sorafenib and wh-4 on the proliferation of liver cancer cells was investigated. The results showed that sorafenib with wh-4 additively suppressed the proliferation of liver cancer cells. The colony formation of liver cancer cells decreased significantly in response to the combination treatment of sorafenib with wh-4, and it also induced the apoptosis of liver cancer cells. Western blot analysis demonstrated decreased expression of $\mathrm{Bcl} 2$, and increased expression of Bax in liver cancer cells treated with a combination of sorafenib and wh-4. Moreover, the migration of liver cancer cells was inhibited. The combination treatment of sorafenib with wh-4 reduced the expression levels of $A B C B 1$ and $A B C G 2$ which are responsible for resistance. Finally, STAT3 overexpression abolished the proliferation inhibition effect of sorafenib with wh-4 on liver cancer cells, and sorafenib and wh-4 suppressed the proliferation of liver cancer cells by STAT3 pathway. Together, these results suggest that sorafenib-wh4 combination treatment is a potential novel therapeutic approach to suppress the proliferation of liver cancer cells.
\end{abstract}

Correspondence to: Dr Yi-Fei Wang, College of Life Science and Technology, Jinan University, 601 West Huangpu Road, Guangzhou, Guangdong 510632, P.R. China

E-mail: twang-yf@163.com

Dr Ying Wang, College of Food Science and Technology, Zhongkai University of Agriculture and Engineering, 501 Zhongkai Road, Guangzhou, Guangdong 510225, P.R. China

E-mail: 39087419@qq.com

Key words: sorafenib, wh-4, combination treatment, proliferation, hepatocellular carcinoma cells

\section{Introduction}

Hepatocellular carcinoma (HCC) is the leading cause of cancer-associated deaths and is extremely resistant to chemotherapy (1). Due to poor prognosis and lack of effective drugs, the overall survival rate of patients with HCC is below $30 \%(2,3)$. Most patients go undiagnosed until the disease has progressed to an advanced stage (4). Molecular therapy targeted against specific molecules in tumor cells or their niche is currently the standard treatment for patients with advanced liver cancer (5). Sorafenib, a multi-kinase inhibitor, is a Food and Drug Administration (FDA)-approved chemical drug for treating patients with HCC (6-8). However, when treated with sorafenib, the average overall survival of patients is only extended by 2.8 months compared with that of untreated patients. Patients treated with sorafenib either suffer from severe side-effects or show disease progression after the initial response $(4,9)$. Previous studies have shown that sorafenib is no longer effective in patients after months of treatment, which suggests that the shortcomings of sorafenib are associated with the development of drug resistance (10-12). ATP-binding cassette $(\mathrm{ABC})$ transporters are involved in tumor cell multidrug resistance (MDR), such as ABCB1 and $\mathrm{ABCG}$. ABC proteins can transport a wide variety of anticancer drugs, including inhibitors of tyrosine kinases (13). In $\mathrm{HCC}$ cells, ABC proteins are upregulated, which is associated with the activation of survival pathways $(14,15)$. ABCB1 has been associated with decreased median survival time in patients with $\mathrm{HCC}$ and $\mathrm{ABCG} 2$ contributes towards the MDR phenotype in $\mathrm{HCC}(16,17)$.

Wh-4, a heat shock protein 90 (Hsp90) inhibitor, was synthesized in the laboratory and was derived from the existing inhibitor, SNX-2112 (18-23). Hsp90 is a member of a highly conserved family of molecular chaperones present in all eukaryotes (24). Although Hsp90 accounts for only 1-2\% of total cellular protein content, it is responsible for regulating several activities, including client proteins activity, stability, conformation and function $(25,26)$. Hsp90 facilitates metastasis, rapid cell division, resistance and evasion of apoptosis in cancer cells (27). Many kinases, including PI3K, ERK, vascular endothelial growth factor receptor (VEGFR) and insulin-like growth factor receptor, are Hsp90 client proteins (26). These 
functionally important kinases depend on Hsp90 to achieve an active conformation or to gain increased stability (25). Cancer cells are dependent on Hsp90, and thus Hsp90 has been successfully used as a target in tumor therapeutics in many clinical trials for Hsp90 inhibitors in multiple tumor types (28). For example, the benzoquinone ansamycin Hsp90 inhibitors, including geldanamycin and its derivative 17-AAG $(26,29,30)$, induced cancer cell apoptosis and disrupted the transcriptional function of HIF1 $\alpha$. Moreover, 17-AAG decreased the colony-formation capacity of lymphoma stem cells (31). In addition, SNX-2112, a novel Hsp90 inhibitor, decreased the cell viability and tumorigenicity of multiple myeloma cells (32).

Although sorafenib, a tyrosine kinase inhibitor, remarkably suppresses the Raf/Ras/MEK/ERK signaling pathway and inhibits receptor tyrosine kinases, including VEGFR, platelet-derived growth factor receptor (PDGFR), and fibroblast growth factor receptor, HCC cells are resistant to sorafenib and its side effects are also severe (33-35). Hsp90 is a molecular chaperone that stabilizes the folding and conformation of proteins in cancer cells. Hsp90 client proteins play an important part in cancer cell proliferation, resistance, and other important cellular processes. According to previous studies, sorafenib interferes with the unfolded protein response $(36,37)$. For example, sorafenib interacts with Hsp90/Hsp70 inhibitors to disrupt the folding of nascent proteins $(38,39)$, which suggests that the combination of sorafenib with wh-4 can effectively inhibit cancer cell proliferation.

Here, we investigated the effect of sorafenib in combination with wh- 4 on liver cancer cells. In addition, we examined the anti-tumor efficacy of a novel Hsp90 inhibitor, wh-4, in liver cancer cells.

\section{Materials and methods}

Cell lines. Liver cancer cell lines SK-HEP-1, which are liver sinusoidal endothelial cells of tumorigenic origin (cat. no. FH0072), Huh7 (cat. no. FH0873) and HepG2 (cat. no. FH0076) were purchased from the FUHENG Biotechnology in Shanghai. The SK-HEP-1 and HepG2 cell lines were authenticated using short-tandem repeat profiling (FUHENG Biotech). The cells were seeded in DMEM (Gibco; Thermo Fisher Scientific, Inc.) supplemented with $1 \%$ penicillin-streptomycin and incubated in a humidified atmosphere of $5 \% \mathrm{CO}_{2}$ at $37^{\circ} \mathrm{C}$. Sorafenib (cat. no. Y0002098), Tris, glycine, SDS and dimethyl sulfoxide (DMSO) were purchased from Sigma-Aldrich (Merck KGaA). Wh-4 (purity $>98.0 \%$ ) was a kind donation from Professor Huang (Serenex, Inc.; Durham, USA). Wh-4 is a benzamides derivative and was designed to inhibit proteins with purine binding sites, which yielded a novel benzamide hit for Hsp90. Synthetic and modeling analyses of this chemical scaffold prompted effort to combine the benzamide with a 1,2,3,9-tetrahydro-4H-carbazol-4-one moiety. The 1,2,3,9-tetrahydro-4H-carbazol-4-one ring system was established by means of combining 1,3-cyclohexanedione and phenyl hydrazine via the Fischer indole synthesis in a Personal Chemistry microwave apparatus. Use of dimedone or the mono-methyl reagent instead of 1,3-cyclohexanedione yielded the related analogs. The purified tetrahydro-4H-carbazol-4-one was then reacted with the desired 4-fluorobenzonitrile in the presence of sodium hydride (40). Wh-4 was dissolved in DMSO, and a 10-mM stock solution in DMSO was prepared. For further use, the stock was diluted in cell culture medium.

MTT assay. The effect of sorafenib and wh-4 on cell proliferation was determined by the MTT (cat. no. KGT525500; Nanjing KeyGen Biotech Co., Ltd.) uptake method. Approximately $3 \times 10^{3}$ cells were seeded in each well of a 96-well plate and incubated for $12 \mathrm{~h}$. On the next day, the cells were exposed to the following treatments: Various concentrations of wh-4 only, $10 \mu \mathrm{M}$ sorafenib only, or a combination of both drugs. The treatment was carried out at $37^{\circ} \mathrm{C}$ for $48 \mathrm{~h}$. Finally, MTT (5 mg/ml; cat. no. 96992; Sigma-Aldrich; Merck KGaA) was added to each well and incubated at $37^{\circ} \mathrm{C}$ for $4 \mathrm{~h}$. The absorbance was measured using a Shimadzu reader (Thermo Fisher Scientific, Inc.) at $570 \mathrm{~nm}$.

Western blotting. Cells were lysed in ice-cold 1\% SDS buffer and centrifuged at $8,000 \times \mathrm{g}$ at $4^{\circ} \mathrm{C}$ for $10 \mathrm{~min}$. The protein concentration was determined using the BCA method (Beyotime Institute of Biotechnology, Inc.). Then, $20 \mu \mathrm{g}$ protein was separated by $12 \%$ SDS-PAGE and transferred to $0.20-\mu \mathrm{m}$ polyvinylidene fluoride membranes (cat. no. ISEQ00010; EMD Millipore). The polyvinylidene fluoride membranes were blocked with $5.0 \%$ milk in $0.1 \%$ TBST $(0.1 \%$ Tween-20 in Tris-base buffer, $\mathrm{pH}$ 7.0) at room temperature for $1.5 \mathrm{~h}$. Then, the membrane was incubated with primary antibodies at $4^{\circ} \mathrm{C}$ for $16 \mathrm{~h}$. The primary antibodies used in this study (all purchased from Cell Signaling Technology, Inc.) included anti-Bcl2 (1:1,000; cat. no. 15071), anti-Bax (1:1,000; cat. no. 5023), STAT3 (1:1,000; cat. no. 12640), phosphorylated (p)STAT3 ${ }^{\mathrm{Y} 705}(1: 1,000$; cat. no. 9145), caspase-3 (1:1,000; cat. no. 9668), caspase-9 (1:1,000; cat. no. 9508), ABCB1 (1:1,000; cat. no. 13342), ABCG2 (1:1,000; cat. no. 42078) and GAPDH (1:1,000; cat. no. 5174;). The membrane was washed with $0.1 \%$ TBST buffer three times and subsequently incubated with horseradish peroxidase-conjugated secondary antibody (1:8,000; cat. no. 7074; Cell Signaling Technology, Inc.) for $1 \mathrm{~h}$ at $37^{\circ} \mathrm{C}$ before being treated with the chemiluminescence reagent (EMD Millipore) and exposed to Kodak film.

Reverse transcription-quantitative $(R T-q) P C R$ analysis. Total RNA (tRNA) was extracted using the TRIzol Reagent kit (cat. no. DP424; Tiangen Biotech Co., Ltd.) and treated with RNAse-free DNAase and diethyl pyrocarbonate (Nanjing KeyGen Biotech Co., Ltd.). The extracted tRNA was reverse-transcribed into cDNA using PrimerScript Master mix (Bio-Rad Biotechnology, Inc.) according to the manufacturer's instructions. qPCR was used to evaluate the expression level of genes in the RT-PCR system (CFX96 Real-Time System; Bio-Rad Laboratories, Inc.) using primers (Shanghai GeneChem Co., Ltd.). Primer sequences were as follows: ABCB1, forward, 5'-AGGTGGCGTGGAAGGTCC GGTCC-3', and reverse, 5'-GGTGAGGCCGTGGTAATC GGTGA-3'; ABCG2, forward, 5'-GGTCGGACCTGGTAG GTAATG-3', and reverse, 5'-AATGTTGACCGGTGGCAA GTTA-3'; GAPDH, forward, 5'-AGCCACATCGCTCAGAC AC-3, and reverse, 5'-GCCCAATACGACCAAATCC-3. The following PCR conditions were used on the Light Cycler: $95^{\circ} \mathrm{C}$ for $5 \mathrm{sec}, 60^{\circ} \mathrm{C}$ for $5 \mathrm{sec}$, followed by 40 cycles of $94^{\circ} \mathrm{C}$ for 
$20 \mathrm{sec}$ and $60^{\circ} \mathrm{C}$ for $1 \mathrm{~min}$ in a $25-\mu 1$ reaction volume. Relative expression levels were analyzed by the $2^{-\Delta \Delta \mathrm{Cq}}$ method with GAPDH as the reference gene (41). All experiments were performed three times.

Colony-formation assay. Approximately $5 \times 10^{3}$ cells were seeded in each well of a 6-well dish. On the next day, the cells were treated with different concentrations of wh-4 only, sorafenib only, or a combination of both drugs $(5 \mu \mathrm{M}$ sorafenib, $5 \mu \mathrm{M}$ wh-4) and incubated at $4^{\circ} \mathrm{C}$ for another $48 \mathrm{~h}$. The plates were subsequently incubated at $37^{\circ} \mathrm{C}$ in a humidified incubator for 21 days. Culture media was replenished every 3 days. The colonies of more than 40 cells was visualized as positive and stained with $0.5 \%$ crystal violet for $30 \mathrm{~min}$ at $37^{\circ} \mathrm{C}$ (cat. no. KGA229; Nanjing KeyGen Biotech Co., Ltd.). The numbers of positive colonies were counted under a light microscope (Nikon Corporation) and calculated. The number of more than 40 cells was divided by 5,000, in order to obtain the colon-forming efficiencies. The experiments were repeated three times.

Scratch wound healing assay. The combined effects of sorafenib and wh-4 treatment on cell migration were examined using a scratch wound healing assay. Cells were counted, and $2 \times 10^{5}$ cells were seeded into $60-\mathrm{mm}$ cell culture plates (Corning, Inc.) in DMEM medium (Gibco; Thermo Fisher Scientific, Inc.) supplemented with $10 \%$ fetal bovine serum (Hangzhou Sijiqing Biological Engineering Materials Co., Ltd.). Upon reaching $80 \%$ confluence, the bottom of the plates was scratched gently and slowly with a sterile pipette tip, and the gap created in the attached monolayer of cells was photographed (Nikon Corporation). Then, the cells were cultured in in DMEM medium (Gibco; Thermo Fisher Scientific, Inc.) supplemented with $10 \%$ fetal bovine serum (Hangzhou Sijiqing Biological Engineering Materials Co., Ltd.). After $48 \mathrm{~h}$, the migration distance of the cells was captured under a light microscope (Nikon Corporation) and calculated by subtracting the gap distance recorded at $0 \mathrm{~h}$ from the current gap distance. Data were collected from three independent experiments.

Cell apoptosis analysis. The cells were exposed to the following treatments: Various concentrations of wh- 4 only, sorafenib only, or a combination of both drugs. The cells were incubated with the drugs at $37^{\circ} \mathrm{C}$ for $48 \mathrm{~h}$. Subsequently, the cells were harvested and washed three times with phosphate buffer, followed by the addition of $0.5 \mathrm{ml}$ binding reagent and $5 \mu 1$ Annexin V-FITC (cat. no. KGAV116; Nanjing KeyGen Biotech Co., Ltd.). After 30 min, the cells were stained with $5 \mu 1$ 7-AAD (cat. no. KGAV116; Nanjing KeyGen Biotech Co., Ltd.) for $15 \mathrm{~min}$ at room temperature according to the manufacturer's instructions. Apoptosis in the cells was examined using flow cytometry (BD FACSCalibur). All data were analyzed using the FlowJo 10 software (FlowJo, Becton, Dickinson \& Company).

Cell Ki-67 analysis. A total of 50,000 cells were seeded in 6-cm plates (Corning, Inc.). They were exposed to the following treatments at $37^{\circ} \mathrm{C}$ : wh- 4 only, sorafenib only, or a combination treatment of both drugs. After $48 \mathrm{~h}$, the cells were collected, washed, and incubated with Alexa Fluor 488-conjugated Ki-67 antibody (1:100; cat. no. ab197234; Abcam) at room temperature for $1.5 \mathrm{~h}$. Images were captured (Nikon Corporation). Image-Pro Plus was used to calculate the fluorescence intensity of Ki-67 cells (Media Cybernetics).

Plasmid construct, siRNA sequence and transient transfection. STAT3 mRNA was extracted from HepG2 cells and cloned into the pcDNA3.1 vector (Shanghai GenePharma Co., Ltd.). STAT3 DNA sequencing was performed by Sangon Biotech Co., Ltd. The vectors were purified using a plasmid filter maxiprep kit (cat. no. K210027; Thermo Fisher Scientific Inc.). The STAT3 recombinant plasmid (pcDNA3.1-STAT3) was transfected using the $5 \mu$ l Lipofectamine ${ }^{\circledR} 3000$ reagent (cat. no. L300-015; Thermo Fisher Scientific, Inc.) according to the manufacturer's instructions. pcDNA3.1-STAT3 recombinant was transfected using a serum-free medium, and after $4 \mathrm{~h}$, the medium was replaced with normal medium. Synthetic small interfering RNA (si)-GFP, si-ABCB1 and ABCG2 had the following sequences: GFP sense, 5'-GCAUCAAGG UGAACUUCAA-3'; GFP antisense, 5'-UUGAAGUUCACC UUGAUGC-3'; ABCB1 sense, 5'-GCGGUUAACCAUCGA GUUA-3'; ABCB1 antisense, 5'-UAACUCGAUGGUUAA CCGC-3'; ABCG2 sense, 5'-GCAAUCAGACCUGGAACA AUU-3'; ABCG2 antisense, 5'-AAUUGUUCCAGGUCU GAUUGC-3'. Then, 100 pmol siRNA were transfected using the $5 \mu$ l Lipofectamine ${ }^{\circledR} 3000$ reagent (cat. no. L300-015; Thermo Fisher Scientific, Inc.) in $5 \% \mathrm{CO}_{2}$ at $37^{\circ} \mathrm{C}$ according to the manufacturer's instructions. Also, $8 \mu \mathrm{g} / \mathrm{ml}$ polybrene (cat. no. G04001; Shanghai GenePharma Co., Ltd.) was used to improve the transfection efficiency. After $4 \mathrm{~h}$ the medium were replaced with normal medium. $72 \mathrm{~h}$ later, the cells were harvested.

Statistical analysis. Statistical analysis was performed using SPSS 19.0 software (SPSS, Inc.). All data are presented as the mean \pm SD for at least three independent experiments. Student's t-test was used for two-group comparisons, whilst comparisons among multiple groups were performed using a one-way ANOVA followed by Tukey's test. Results with $\mathrm{P}<0.05$ were considered to indicate a statistically significant difference.

\section{Results}

Combination of sorafenib with wh-4 demonstrates an inhibitory effect on the proliferation of liver cancer cells. The chemical structure of wh-4 is shown in Fig. 1A. The MTT assay was used to evaluate the inhibitory effect of the drugs on the proliferation of liver cancer cells. Liver cancer cells were treated with various concentrations of sorafenib or wh- 4 for $24 \mathrm{~h}$. It was found that the $\mathrm{IC}_{50}$ values for wh- 4 and sorafenib at $24 \mathrm{~h}$ were 4.90 and $4.62 \mu \mathrm{M}$, respectively, in SK-HEP-1 (Fig. 1B). In addition, the $\mathrm{IC}_{50}$ values for wh-4 and sorafenib at $24 \mathrm{~h}$ in Huh7 cells were 4.32 and $5.35 \mu \mathrm{M}$, respectively (Fig. 1C). Furthermore, a colony-formation assay was performed to evaluate the anti-tumor effect of the drugs, and a similar outcome was observed (Fig. 2A and B). The colony-formation experiments showed that the combination of $5 \mu \mathrm{M}$ sorafenib and $5 \mu \mathrm{M}$ wh-4 significantly inhibited colony 

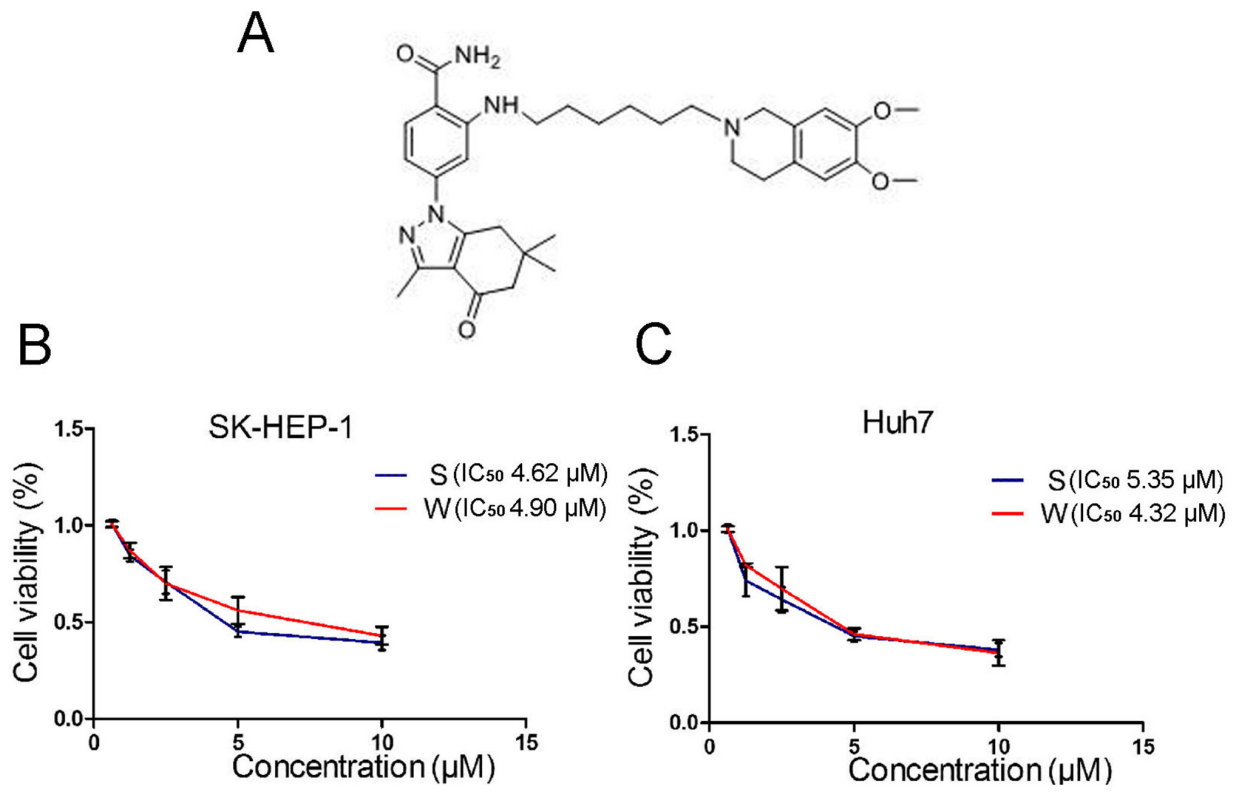

Figure 1. Cell viability of liver cancer cells analyzed by MTT assay. (A) Formal chemical structure of wh-4. (B and C) Three thousand cells were seeded in a 96-well dish and incubated for $\sim 12 \mathrm{~h}$. Cell were then treated with the indicated doses of sorafenib and wh- 4 for $48 \mathrm{~h}$. The effect of sorafenib, wh- 4 and combination treatment on the cell viability of Huh7, SK-HEP-1 cells was evaluated by the MTT assay. $\mathrm{IC}_{50}$, half-maximal inhibitory concentration; S, sorafenib; W, wh-4.

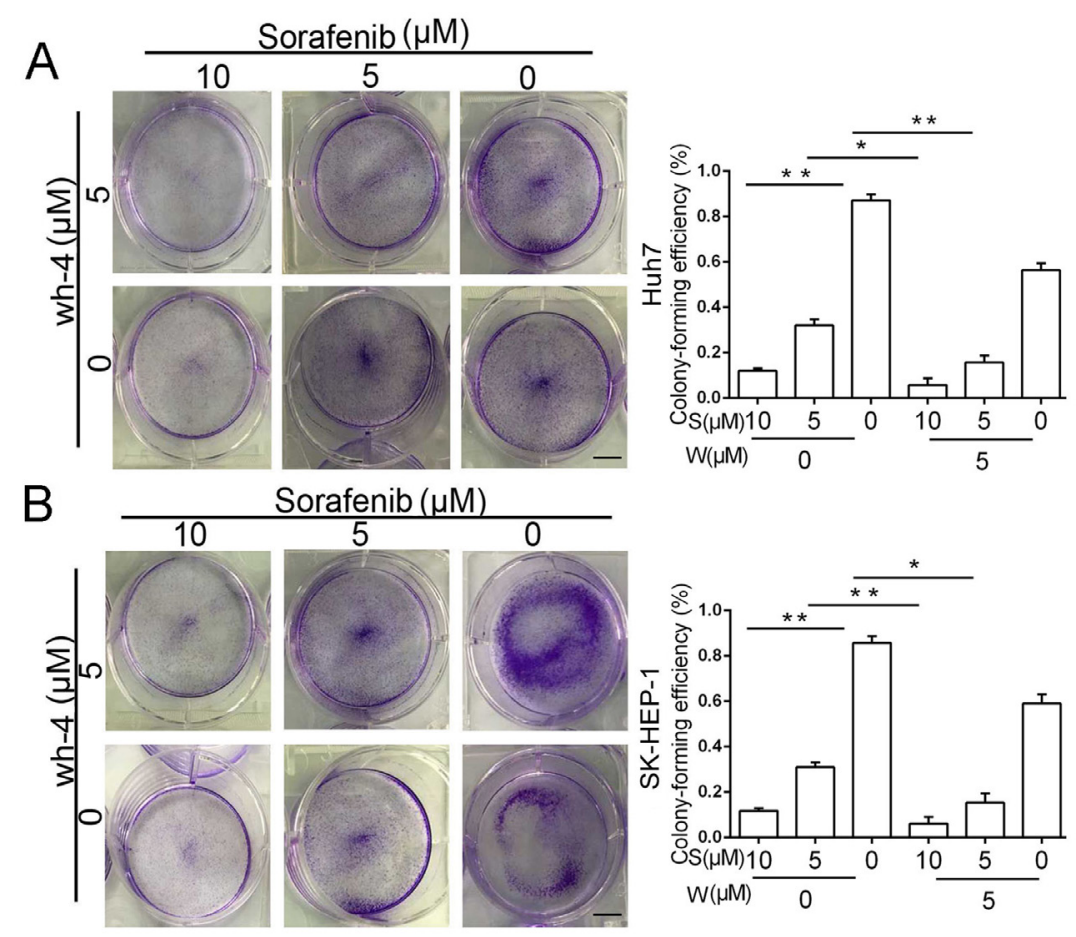

Figure 2. Sorafenib combined with wh-4 additively decreases the viability of liver cancer cells. (A and B) Fifty thousand cells were seeded in a 6-well dish, and the cells were treated with sorafenib, wh- 4 or their combination for $48 \mathrm{~h}$. The plates were incubated at $37^{\circ} \mathrm{C}$ in a humidified incubator for 21 days. Culture media was replenished every 3 days. The colonies of more than 40 cells was visualized as positive and stained with $0.5 \%$ crystal violet for 30 min. Scale bar, $10 \mathrm{~mm}$. ${ }^{*} \mathrm{P}<0.05$ and ${ }^{* *} \mathrm{P}<0.01$. S, sorafenib; $\mathrm{W}$, wh- 4 .

formation of liver cancer cells. The combination treatment decreased the efficiency of the colony formation more significantly than with sorafenib or wh-4 alone.

Combination of sorafenib with wh-4 induces apoptosis in liver cancer cells. Flow cytometry results demonstrated that the percentage of Huh7 cells undergoing apoptosis was
(54.4 \pm 5.64$) \%$ when treated with $5 \mu \mathrm{M}$ wh- 4 and $(58.7 \pm 6.51) \%$ when treated with $5 \mu \mathrm{M}$ sorafenib (Fig. 3A). The fraction of apoptotic cells after the combination treatment of sorafenib and wh- 4 was $(66.6 \pm 6.22) \%$, which was higher than that after single-drug therapy (Fig. 3A). Furthermore the effect of combination treatment with the two drugs were examined in SK-HEP-1 cells. The percentage of SK-HEP-1 cells 
A

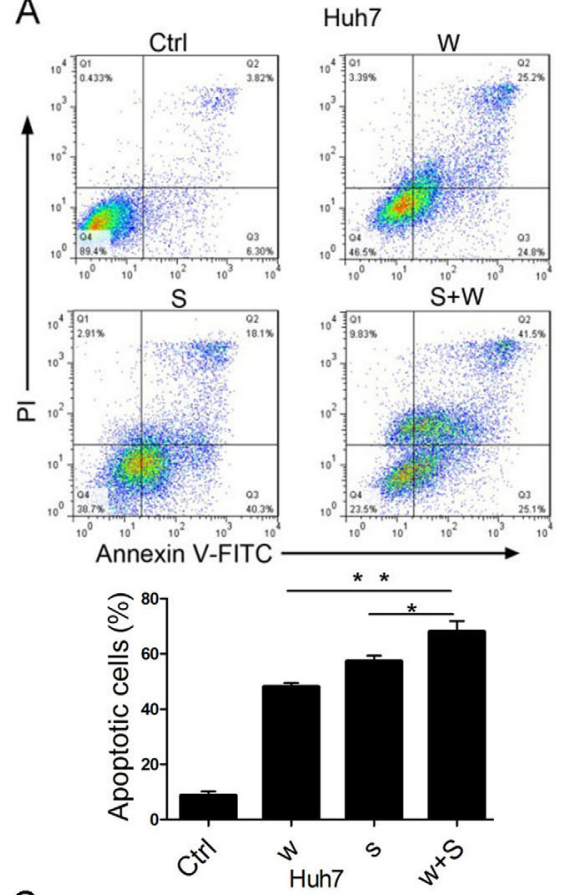

C

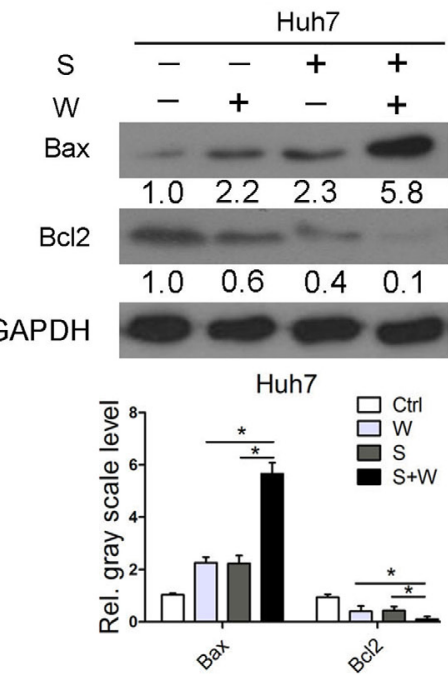

B
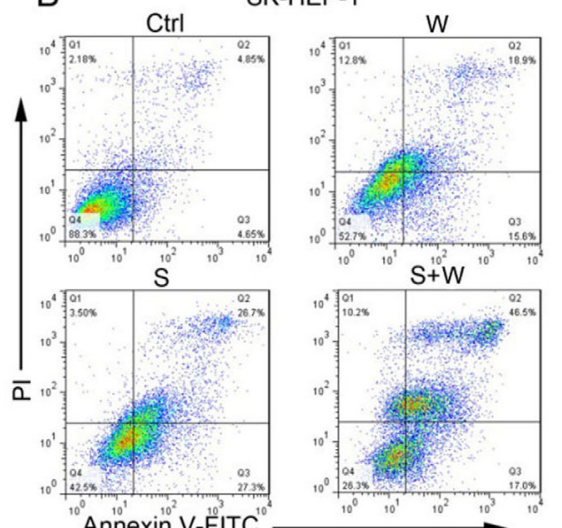

Annexin V-FITC

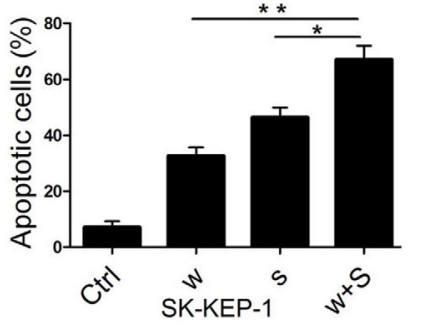

D

$s$

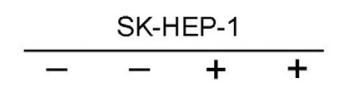

$w-+-+$

Bax

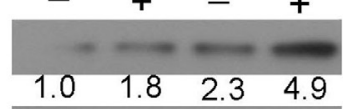

$\mathrm{Bcl} 2$

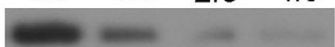

GAPDH

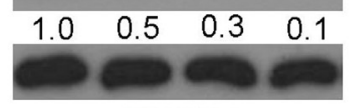

SK-HEP-1

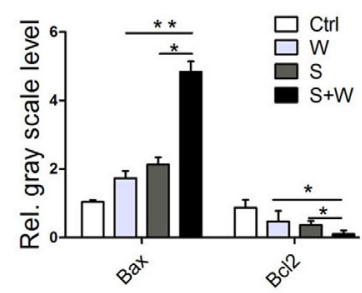

Figure 3. Flow cytometry and western blot assays demonstrates that combination treatment with sorafenib and wh-4 additively induces liver cancer cell apoptosis. (A and B) Analysis of liver cancer cells treated with sorafenib $(5 \mu \mathrm{M})$, wh-4 $(5 \mu \mathrm{M})$ and their combination by flow cytometry. The combination contained $5 \mu \mathrm{M}$ each of sorafenib and wh-4. After $24 \mathrm{~h}$, cells were collected and the effects were analyzed by flow cytometry. (C and D) Analysis of liver cancer cells treated with $5 \mu \mathrm{M}$ sorafenib, $5 \mu \mathrm{M}$ wh- 4 and their combination ( $5 \mu \mathrm{M}$ concentration of each drug) by western blotting. GAPDH was considered as the loading control. ${ }^{*} \mathrm{P}<0.05$ and ${ }^{* *} \mathrm{P}<0.01$. S, sorafenib; W, wh-4; Ctrl, control; Rel., relative.

undergoing apoptosis after the combination treatment was $(63.5 \pm 5.85) \%$, which was higher than that after single-drug therapy with sorafenib or wh-4. The fraction of apoptotic SK-HEP-1 cells after treatment with sorafenib or wh-4 alone was $(54.0 \pm 6.34) \%$ and $(34.5 \pm 4.89) \%$, respectively (Fig. 3B). The aforementioned results demonstrated that the Bax levels in Huh7 and SK-HEP-1 cells notably increased when subjected to combination treatment compared to those with either drug alone (Fig. 3C and D). The levels of Bcl2 in Huh7 and SK-HEP-1 cells were significantly decreased after combination treatment with the two drugs (Fig. 3C and D). In addition, the caspase-3 and caspase-9 levels were not significantly different (Fig. S1). Collectively, the aforementioned results suggested that combination treatment with sorafenib and wh-4 increased apoptosis in liver cancer cells.
Sorafenib with wh-4 suppresses liver cancer cell proliferation and migration. The scratch wound healing assay demonstrated that both sorafenib and wh-4 inhibited the migration of liver cancer cells. The data suggested that the combination treatment with sorafenib and wh-4 significantly inhibited Huh7 migration (Fig. 4A). A similar additive effect of sorafenib and wh- 4 was also observed in SK-HEP-1 cells (Fig. 4B). In addition, the Ki-67 assay demonstrated that sorafenib and wh-4 combination treatment remarkably decreased the proliferation of Huh7 and SK-HEP-1 cells (Fig. 4C and D). The fluorescence intensity level in sorafenib with wh-4 combination treatment was notably decreased (Fig. 4C and D). The aforementioned observations indicated that sorafenib with wh-4 suppressed liver cancer cell proliferation. 

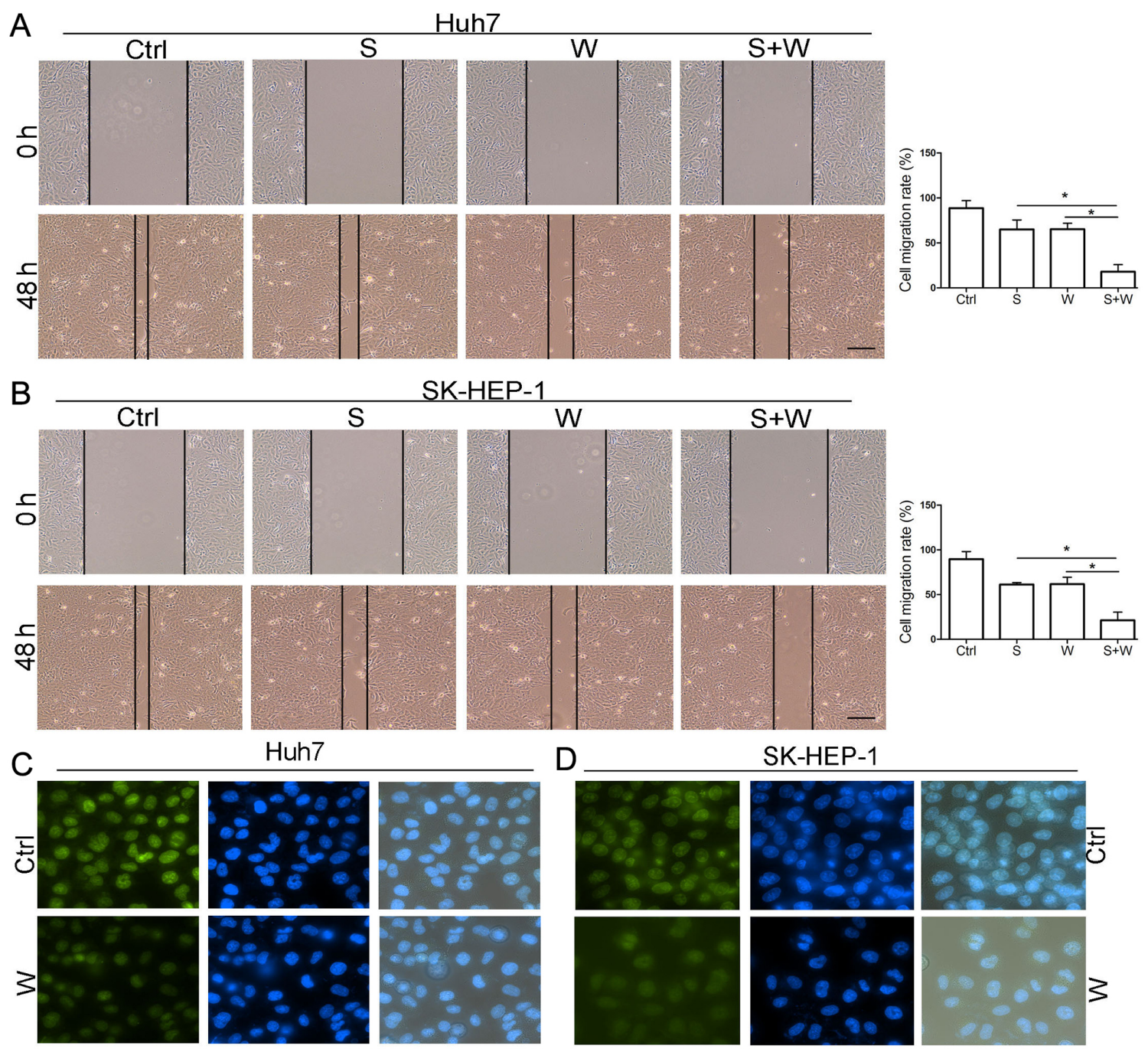

Huh7
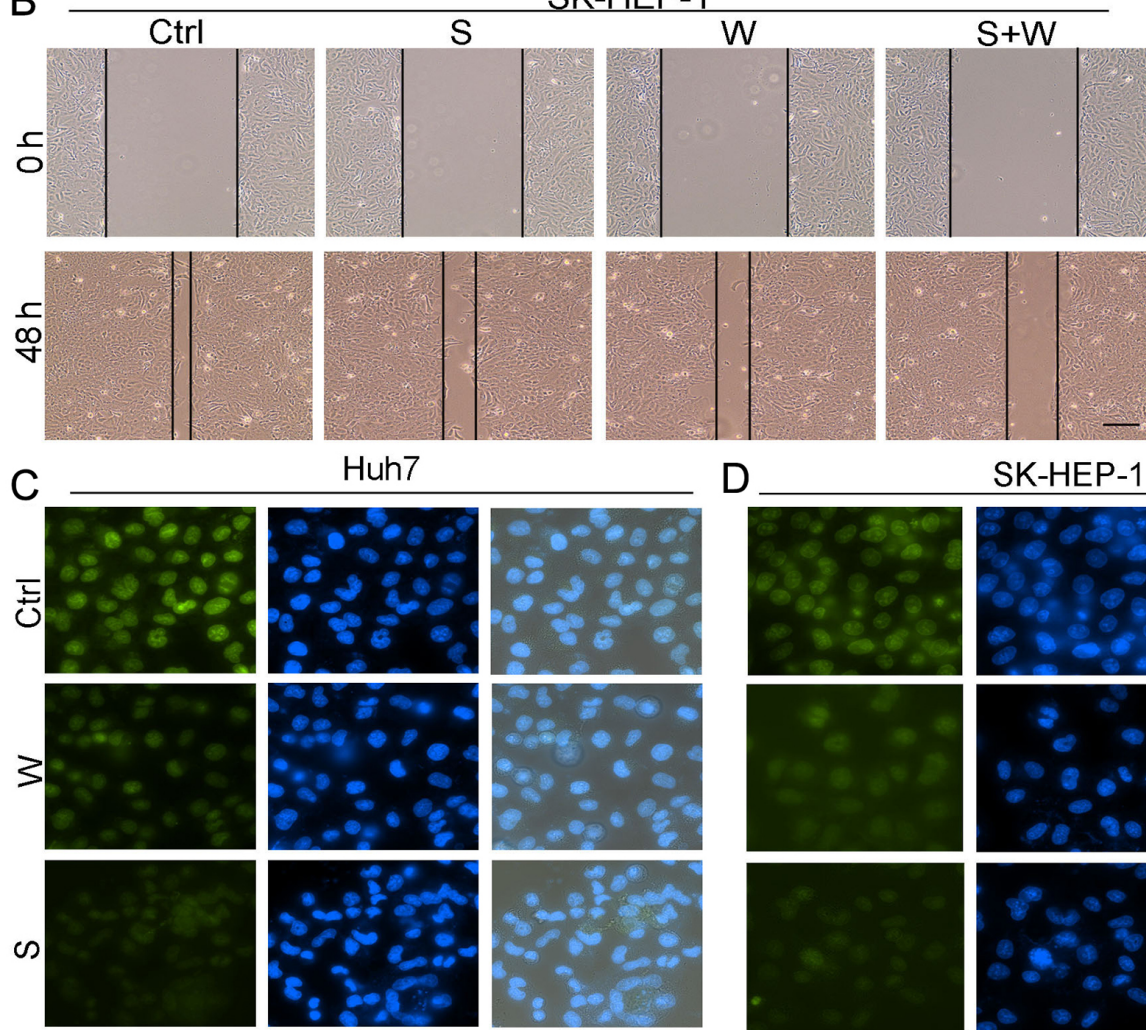

D
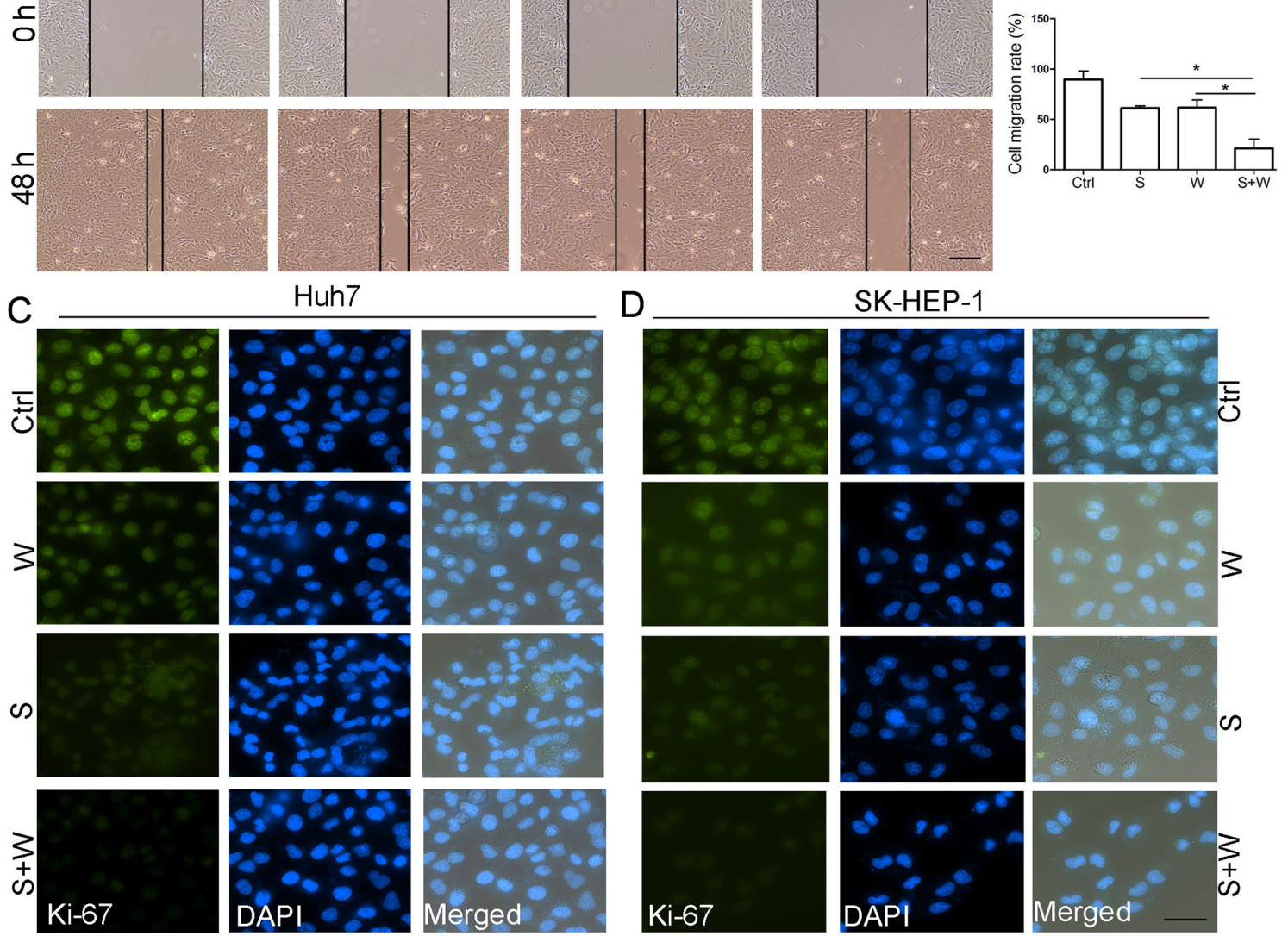

SK-HEP-1
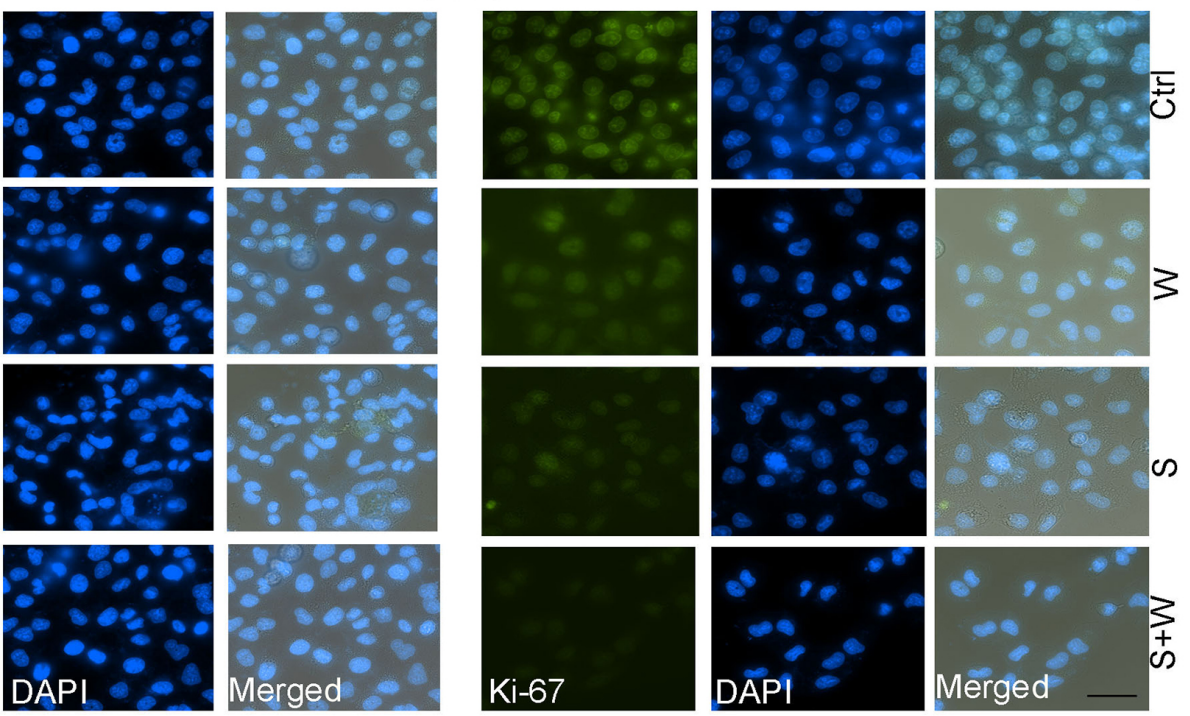

Huh7
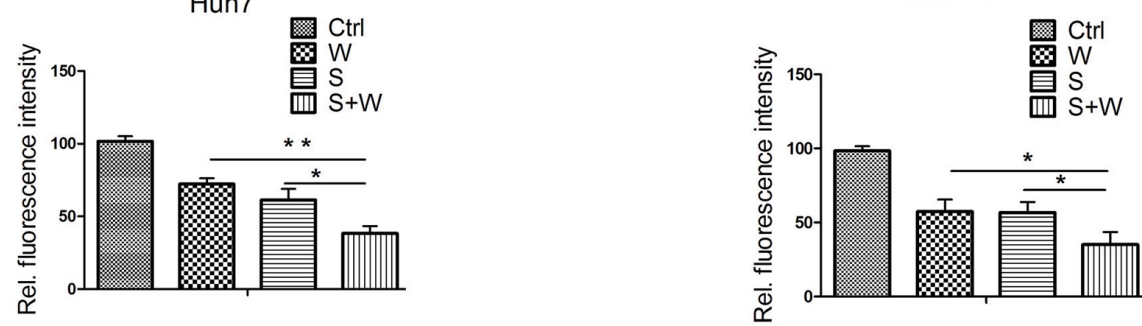

Figure 4. Sorafenib with wh-4 suppresses cell migration. (A and B) Cells were subjected to 6-well plates. The cells were treated with $5 \mu \mathrm{M}$ sorafenib, $5 \mu \mathrm{M}$ wh-4 and their combination ( $5 \mu \mathrm{M}$ each of sorafenib and wh-4) for $24 \mathrm{~h}$. A $200-\mu \mathrm{l}$ sterile pipette tip was used to scratch the dish bottom. After $48 \mathrm{~h}$, the width was recorded using captured images. The combination contained sorafenib $(5 \mu \mathrm{M})$ and wh-4 $(5 \mu \mathrm{M})$. Scale bar, $50 \mu \mathrm{m}$. (C and D) Ki-67 analysis of cell proliferation. Cells were treated with sorafenib $(5 \mu \mathrm{M})$, wh- $4(5 \mu \mathrm{M})$ and their combination $(5 \mu \mathrm{M}$ concentration of each drug) for $24 \mathrm{~h}$. Scale bar, $100 \mu \mathrm{m}$. ${ }^{*} \mathrm{P}<0.05$ and $^{* *} \mathrm{P}<0.01$. S, sorafenib; W, wh-4; Ctrl, control; Rel., relative.

Combination treatment with sorafenib and wh-4 decreases the levels of $\mathrm{ABC}$ transporter genes. $\mathrm{ABCB} 1$ and $\mathrm{ABCG} 2$ play an important part in liver cancer cells proliferation $(42,43)$.
The si- $A B C B 1$ and $A B C G 2$ silencing efficiency was evaluated (Fig. S2). Knockdown of $A B C B 1$ and $A B C G 2$ inhibited the proliferation of liver cancer cells (Fig. 5A and B). However, 

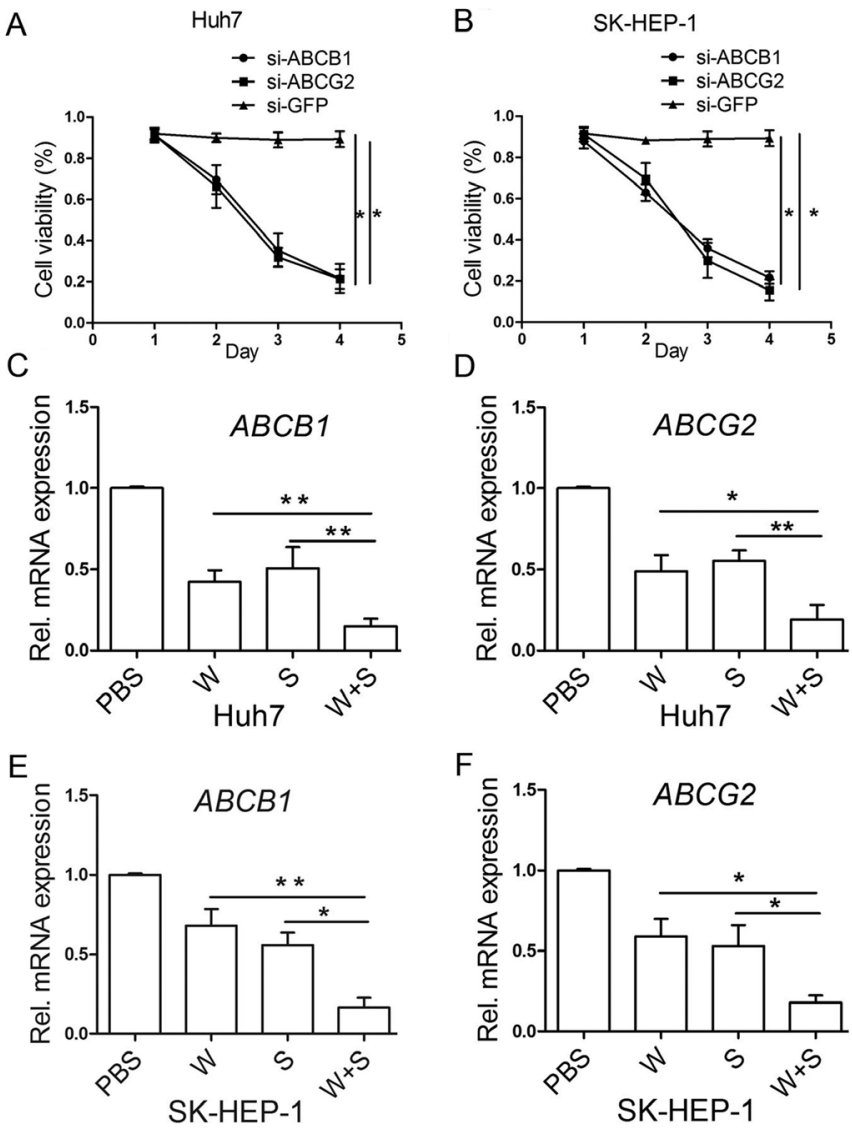

Figure 5. Sorafenib with wh-4 decrease the levels of chemoresistant genes (A and B) Cell proliferation analysis of liver cancer cells after $A B C B 1$ and $A B C G 2$ knockdown. (C and $\mathrm{D})$ Cell viability analysis of liver cancer cells by MTT assay. The liver cancer cells were knockdown with siRNA. (E and F) Reverse transcription-quantitative PCR analysis of $A B C B 1$ and $A B C G 2$. Tumor cells were treated with sorafenib $(5 \mu \mathrm{M})$, wh-4 $(5 \mu \mathrm{M})$ and their combination ( $5 \mu \mathrm{M}$ concentration of each drug) for $24 \mathrm{~h}$. ${ }^{*} \mathrm{P}<0.05$ and ${ }^{* *} \mathrm{P}<0.01$. S, sorafenib; W, wh-4; siRNA/si-, small interfering RNA; Rel., relative.

the mechanism by which sorafenib leads to the development of resistance remains unclear. After examining the effects of the drugs on cell proliferation, the expression of ABC transporter genes that are responsible for drug resistance were further investigated. The results demonstrated that the combination treatment with sorafenib and wh-4 significantly decreased the expression levels of $A B C B 1$ and $A B C G 2$ in Huh7 cells (Fig. 5C and D). Next, the levels of $A B C B 1$ and $A B C G 2$ were examined in SK-HEP-1 cells. The levels of $A B C B 1$ and $A B C G 2$ were also decreased after combined treatment with sorafenib and wh-4 (Fig. 5E and F). However, the changes in the expression level of P-glycoprotein (P-gp)-encoded and breast cancer resistance protein-encoded ABCG2 were not observed after the liver cancer cells were treated with the chemicals (Fig. S3). The aforementioned results demonstrated that the combination treatment decreased the resistance level in treated cells.

Sorafenib and wh-4 additively inhibit liver cancer cell proliferation by suppressing the STAT3 signaling pathway. The potential molecular mechanism of the additive inhibition of liver cancer cell proliferation by combination treatment with sorafenib and wh- 4 was further explored. Individual treatment with sorafenib and wh-4 decreased the phosphorylation level of $\mathrm{p}-\mathrm{STAT} 3^{\mathrm{Y} 705}$ in both Huh7 and SK-HEP-1 cells (Fig. 6A and B). To investigate whether STAT3 mediates the proliferation of cells treated with a combination of sorafenib and wh-4, a STAT3 overexpression vector was constructed. The pcDNA3.1-STAT3 vector efficiency was analyzed (Fig. S4). As shown in the soft agar assay in Fig. 6C, STAT3 overexpression remarkably reversed the apoptosis induced by combination treatment with sorafenib and wh-4. Similar effects were observed in SK-HEP-1 cells (Fig. 6D), indicating that this reversal of apoptosis was not a cell-line-specific effect. The aforementioned results suggested that sorafenib with wh-4 may suppress the proliferation of liver cancer cells by the STAT3 pathway.

\section{Discussion}

The present study reported that treatment with sorafenib suppressed the proliferation of live cancer cells. This inhibitory effect of sorafenib was significantly enhanced in combination with the Hsp90 inhibitor wh-4, suggesting an additive mechanism of action of these drugs on the inhibition of liver cancer cell proliferation.

Patients with HCC are diagnosed at intermediate or advanced stages when therapies are no longer effective (44). Sorafenib is the first anti-tumor drug approved by the FDA for treating patients with HCC (45). Clinical trials demonstrated that sorafenib prolonged the median overall survival time of patients by about $3-5$ months $(9,46,47)$. However, the side effects of this treatment, including anorexia, diarrhea, vomiting and squamous cell carcinoma are apparent (48). In addition, the drug is not effective for all patients with liver cancer, and some patients develop resistance (9). The ABC transporters play a key role in liver cancer cells proliferation (49). In the present study, it was found that the expression of ABC transporter genes was decreased in Huh7 and SK-HEP-1 cells (Fig. 5), suggesting that the chemoresistance was partially limited. In addition, knockdown of $A B C B 1$ and $A B C G 2$ inhibited the proliferation of liver cancer cells in the present study. Combination treatment with sorafenib and wh-4 additively decreased the resistance in liver cancer cells. In Fig. 5A and B, si-GFP was used as a control and the Fig. S2 results demonstrated that the si-ABCB1 partly decreased the expression level of ABCB1. Also, si-ABCG2 demonstrated the same silencing effect.

The development of drug resistance is a major challenge in the treatment of patients with HCC. Thus, a more rational treatment plan should focus on combining two or more therapeutic methods. Wh-4 is a derivative of SNX-2112, and SNX-2112 inhibits target proteins, such as Akt, p38, MAPK and Erk that play a crucial role in regulating cell survival, proliferation, resistance and homeostasis (25). In addition, the anticancer activity of sorafenib is attributed to its multi-kinase inhibitory function on several signaling pathways, such as Raf-1, B-Raf, and the receptor tyrosine kinase activity of VEGFRs and PDGFR- $\beta$ (50). Induction of apoptosis in HCC cells suggests that sorafenib might promote apoptosis in other cancer cells such as prostate, breast and colorectal cancer cells (51-53). According to previous studies, the anti-tumor activity of sorafenib on cancer cell proliferation and viability may be useful in combination with other therapies or signaling 

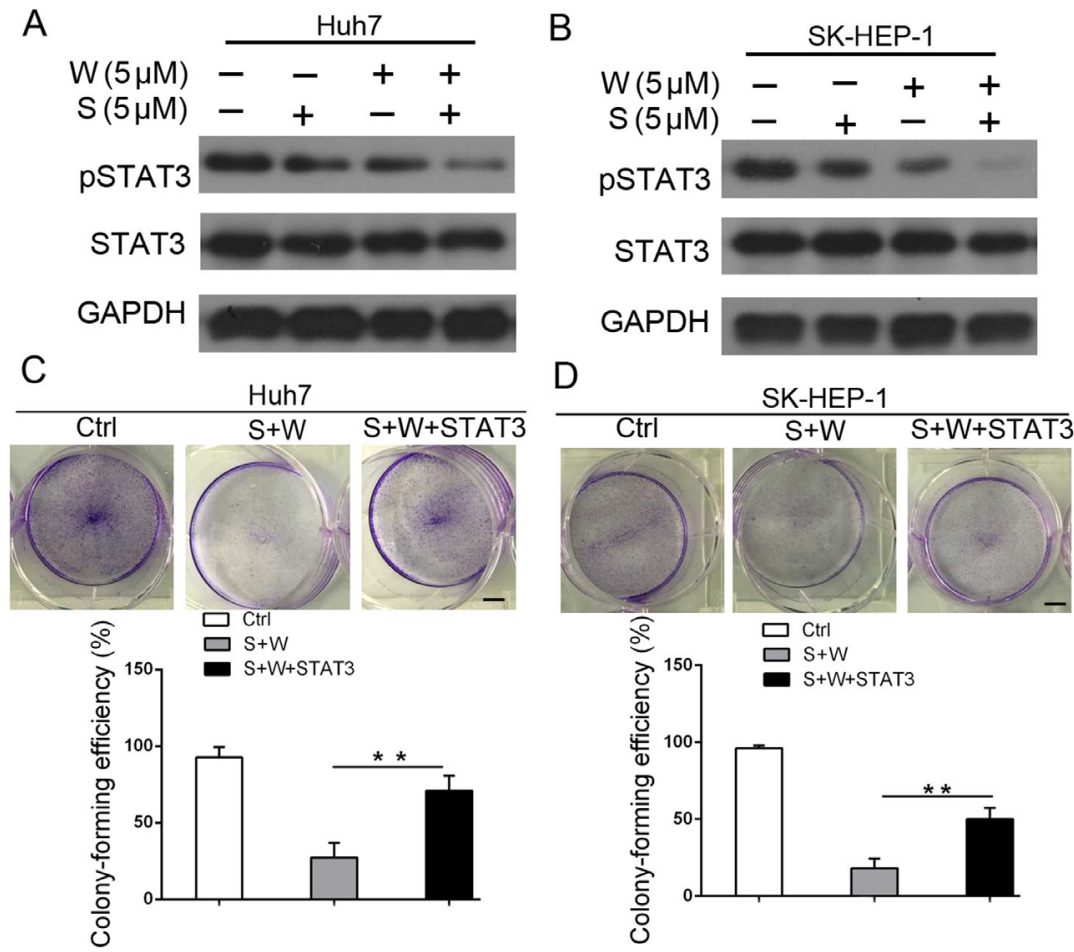

Figure 6. STAT3 signaling pathway mediates liver cancer cell apoptosis induced by sorafenib with wh-4. (A and B) Analysis of STAT3 levels in cells treated with sorafenib $(5 \mu \mathrm{M})$, wh-4 $(5 \mu \mathrm{M})$ and their combination (5 $\mu \mathrm{M}$ sorafenib and $5 \mu \mathrm{M}$ wh-4) for $24 \mathrm{~h}$. GAPDH served as the loading control. (C and D) A colony-formation assay was used to analyze whether STAT3 was key to apoptosis induced by sorafenib with wh-4. Colony formation was detected in cells treated with sorafenib $(5 \mu \mathrm{M})$, wh- $4(5 \mu \mathrm{M})$ and their combination $(5 \mu \mathrm{M}$ sorafenib and $5 \mu \mathrm{M}$ wh- 4$)$ for 48 h. Colonies were stained with $0.5 \%$ crystal violet. Scale bar, $10 \mathrm{~mm} .{ }^{* *} \mathrm{P}<0.01$. S, sorafenib; W, wh-4; Ctrl, control; pSTAT3, phosphorylated STAT3.

transduction pathway inhibitors (38). Therefore, functional inhibition of Hsp90 target proteins in combination with targets of sorafenib may be an effective cancer treatment strategy. In the present study, it was found that combination treatment with sorafenib and wh- 4 additively inhibited the proliferation of liver cancer cells. In addition, it was significant to investigate the additive effect of sorafenib with wh- 4 on liver cancer cells. Drug concentration is critical for anti-tumor effects and it was found the effect of one drug was different at different concentration $(54,55)$. It is, therefore, meaningful to adjust the concentration the sorafenib and wh- 4 .

The changes in the levels of STAT3 were also investigated. Among the STAT family members, STAT3 has received the most attention because it plays a central role in many oncogenic signaling pathways and controls signal transduction pathways in several inflammatory cytokines and growth factors that are implicated in liver damage and repair mechanisms (56). In normal cells, STAT signaling is critical for embryonic development, organogenesis, regulation of cell differentiation, proliferation, growth, and apoptosis, whereas constitutive activation of STAT3 is found in many human types of cancer cell lines and primary tumors including liver, prostate, breast, lung, gastric and head and neck cancer (57-59). STAT3 plays a key role in HCC initiation and progression, and it has been found that its phosphorylation is highly positive in the analysis of HCC biopsies (60-62). Previous more studies demonstrated that STAT3 is an attractive molecular target for the prevention of proliferation and treatment of $\mathrm{HCC}(56,63)$. In the present study, the STAT3 pathway was found to mediate apoptosis induced by combination treatment with sorafenib and wh- 4 .
The results demonstrated that STAT3 is implicated in signal transduction that induces apoptosis in liver cancer cells upon combination treatment with sorafenib and wh-4.

In addition, the limitation of the present study was that in vivo experiments in animal were not conducted. Resistance to sorafenib is a major obstacle for clinical treatment. The present in vitro study demonstrated that sorafenib with wh-4 combination treatment significantly inhibited liver cancer cells proliferation and reduced ABCB1 and ABCG2 expression levels which were responsible for liver cancer cells resistance partly. However, it was not known whether sorafenib with wh- 4 had the antitumor effect in vivo. It was desirable to investigate the effect of sorafenib with wh-4 treatment on liver cancer cells in vivo.

The present study showed that combination treatment with sorafenib and wh- 4 inhibits the proliferation of liver cancer cells and suppresses the development of drug resistance. A novel treatment regimen was also identified to improve the efficacy of sorafenib in patients with liver cancer by targeting the STAT3 pathway. This study demonstrates that combination treatment with sorafenib and wh-4 may present a promising strategy for further clinical therapy of patients with liver cancer.

\section{Acknowledgements}

Not applicable.

\section{Funding}

The author(s) disclosed receipt of the following financial support for the research, authorship, and/or publication of this 
article: This study was supported by grants from the Guangzhou Science and Technology Plan Program (nos. 201904010050 and 202102021276), Medical Scientific Research Fund Project of Guangdong Province (nos. A2018238, A2017312 and A2018540), and Fund of Guangdong Food and Drug Vocational College (nos. 2016YZ001 and 2016YZ023).

\section{Availability of data and materials}

The datasets used and/or analyzed during the current study are available from the corresponding author on reasonable request.

\section{Authors' contributions}

SHC carried out most of the experiments and wrote the manuscript. DDX and PJZ analyzed the data and results. YaW and QYL read and revised the manuscript and contributed to data collection and statistical analysis. ZR and ZL provided technical assistance with several experiments. XW participated in the study design and drafted the paper. HQH conceived the study. YiW and XX participated in the design and coordination of the study. YFW designed the study and revised the manuscript. All authors have read and approved the final manuscript. YFW and SHC have confirmed the authenticity of all the raw data.

\section{Ethics approval and consent to participate}

Not applicable.

\section{Patient consent for publication}

Not applicable.

\section{Competing interests}

The authors declare that they have no competing interests.

\section{References}

1. Torre LA, Bray F, Siegel RL, Ferlay J, Lortet-Tieulent J and Jemal A Global cancer statistics, 2012. CA Cancer J Clin 65: 87-108, 2015.

2. Villanueva A, Minguez B, Forner A, Reig M and Llovet JM: Hepatocellular carcinoma: Novel molecular approaches for diagnosis, prognosis, and therapy. Annu Rev Med 61: 317-328, 2010.

3. Vitale A, Volk ML, Pastorelli D, Lonardi S, Farinati F, Burra P, Angeli P and Cillo U: Use of sorafenib in patients with hepatocellular carcinoma before liver transplantation: A cost-benefit analysis while awaiting data on sorafenib safety. Hepatology 51: 165-173, 2010.

4. Reyes R, Wani NA, Ghoshal K, Jacob ST and Motiwala T: Sorafenib and 2-Deoxyglucose synergistically inhibit proliferation of both Sorafenib-Sensitive and -Resistant HCC cells by inhibiting ATP production. Gene Expr 17: 129-140, 2017.

5. Shen YC, Hsu C and Cheng AL: Molecular targeted therapy for advanced hepatocellular carcinoma: Current status and future perspectives. J Gastroenterol 45: 794-807, 2010.

6. Palmer DH: Sorafenib in advanced hepatocellular carcinoma. N Engl J Med 359: 2498-2499, 2008.

7. Johnson $P$ and Billingham L: Sorafenib for liver cancer: The horizon broadens. Lancet Oncol 10: 4-5, 2009.

8. Tejeda-Maldonado J, Garcia-Juarez I, Aguirre-Valadez J, González-Aguirre A, Vilatobá-Chapa M, Armengol-Alonso A, Escobar-Penagos F, Torre A, Sánchez-Ávila JF and Carrillo-Pérez DL: Diagnosis and treatment of hepatocellular carcinoma: An update. World J Hepatol 7: 362-376, 2015.
9. Llovet JM, Ricci S, Mazzaferro V, Hilgard P, Gane E, Blanc JF, de Oliveira AC, Santoro A, Raoul JL, Forner A, et al: Sorafenib in advanced hepatocellular carcinoma. N Engl J Med 359: 378-390, 2008.

10. Villanueva A and Llovet JM: Second-line therapies in hepatocellular carcinoma: Emergence of resistance to sorafenib. Clin Cancer Res 18: 1824-1826, 2012.

11. Xin HW, Ambe CM, Hari DM, Wiegand GW, Miller TC, Chen JQ, Anderson AJ, Ray S, Mullinax JE, Koizumi T, et al: Label-retaining liver cancer cells are relatively resistant to sorafenib. Gut 62: 1777-1786, 2013.

12. Tai WT, Cheng AL, Shiau CW, Liu CY, Ko CH, Lin MW, Chen PJ and Chen KF: Dovitinib induces apoptosis and overcomes sorafenib resistance in hepatocellular carcinoma through SHP-1-mediated inhibition of STAT3. Mol Cancer Ther 11: 452-463, 2012.

13. Marin JJ, Monte MJ, Blazquez AG, Macias RI, Serrano MA and Briz O: The role of reduced intracellular concentrations of active drugs in the lack of response to anticancer chemotherapy. Acta Pharmacol Sin 35: 1-10, 2014.

14. Marin JJG, Macias RIR, Monte MJ, Romero MR, Asensio M, Sanchez-Martin A, Cives-Losada C, Temprano AG, Espinosa-Escudero R, Reviejo M, et al: Molecular bases of drug resistance in hepatocellular carcinoma. Cancers 12: 1663, 2020.

15. Wang XQ, Ongkeko WM, Chen L, Yang ZF, Lu P, Chen KK, Lopez JP, Poon RT and Fan ST: Octamer 4 (Oct4) mediates chemotherapeutic drug resistance in liver cancer cells through a potential Oct4-AKT-ATP-binding cassette G2 pathway. Hepatology 52: 528-539, 2010.

16. Gao B, Yang FM, Yu ZT, Li R, Xie F, Chen J, Luo HJ and Zhang JC: Relationship between the expression of MDR1 in hepatocellular cancer and its biological behaviors. Int J Clin Exp Pathol 8: 6995-7001, 2015.

17. Nies AT, Konig J, Pfannschmidt M, Klar E, Hofmann WJ and Keppler D: Expression of the multidrug resistance proteins MRP2 and MRP3 in human hepatocellular carcinoma. Int J Cancer 94: 492-499, 2001.

18. Wang S, Du Z, Luo J, Wang X, Li H, Liu Y, Zhang Y, Ma J, Xiao W, Wang $\mathrm{Y}$ and Zhong $\mathrm{X}$ : Inhibition of heat shock protein 90 suppresses squamous carcinogenic progression in a mouse model of esophageal cancer. J Cancer Res Clin Oncol 141: 1405-1416, 2015.

19. Liu Y, Wang X, Wang Y, Zhang Y, Zheng K, Yan H, Zhang L, Chen W, Wang X, Liu Q, et al: Combination of SNX-2112 with 5-FU exhibits antagonistic effect in esophageal cancer cells. Int J Oncol 46: 299-307, 2015.

20. Wang X, Wang S, Liu Y, Ding W, Zheng K, Xiang Y, Liu K, Wang D, Zeng Y, Xia M, et al: The Hsp90 inhibitor SNX-2112 induces apoptosis of human hepatocellular carcinoma cells: The role of ER stress. Biochem Biophys Res Commun 446: 160-166, 2014.

21. Liu KS, Liu H, Qi JH, Liu QY, Liu Z, Xia M, Xing GW, Wang SX and Wang YF: SNX-2112, an Hsp90 inhibitor, induces apoptosis and autophagy via degradation of $\mathrm{Hsp} 90$ client proteins in human melanoma A-375 cells. Cancer Lett 318: 180-188, 2012.

22. Liu KS, Ding WC, Wang SX, Liu Z, Xing GW, Wang Y and Wang YF: The heat shock protein 90 inhibitor SNX-2112 inhibits B16 melanoma cell growth in vitro and in vivo. Oncol Rep 27: 1904-1910, 2012.

23. Bachleitner-Hofmann T, Sun MY, Chen CT, Liska D, Zeng Z, Viale A, Olshen AB, Mittlboeck M, Christensen JG, Rosen N, et al: Antitumor activity of SNX-2112, a synthetic heat shock protein-90 inhibitor, in MET-amplified tumor cells with or without resistance to selective MET Inhibition. Clin Cancer Res 17: 122-133, 2011.

24. Borkovich KA, Farrelly FW, Finkelstein DB, Taulien J and Lindquist $S:$ hsp82 is an essential protein that is required in higher concentrations for growth of cells at higher temperatures. Mol Cell Biol 9: 3919-3930, 1989.

25. Trepel J, Mollapour M, Giaccone G and Neckers L: Targeting the dynamic HSP90 complex in cancer. Nat Rev Cancer 10: 537-549, 2010.

26. Cheng W, Ainiwaer A, Xiao L, Cao Q, Wu G, Yang Y, Mao R and Bao Y: Role of the novel HSP90 inhibitor AUY922 in hepatocellular carcinoma: Potential for therapy. Mol Med Rep 12: 2451-2456, 2015.

27. Sarto C, Binz PA and Mocarelli P: Heat shock proteins in human cancer. Electrophoresis 21: 1218-1226, 2000. 
28. McConnell JR and McAlpine SR: Heat shock proteins 27, 40, and 70 as combinational and dual therapeutic cancer targets. Bioorg Med Chem Lett 23: 1923-1928, 2013.

29. Kamal A, Thao L, Sensintaffar J, Zhang L, Boehm MF, Fritz LC and Burrows FJ: A high-affinity conformation of Hsp90 confers tumour selectivity on Hsp90 inhibitors. Nature 425: 407-410, 2003.

30. Solit DB, Zheng FF, Drobnjak M, Münster PN, Higgins B Verbel D, Heller G, Tong W, Cordon-Cardo C, Agus DB, et al: 17-Allylamino-17-demethoxygeldanamycin induces the degradation of androgen receptor and HER-2/neu and inhibits the growth of prostate cancer xenografts. Clin Cancer Res 8: 986-993, 2002.

31. Newman B, Liu Y, Lee HF, Sun D and Wang Y: HSP90 inhibitor 17-AAG selectively eradicates lymphoma stem cells. Cancer Res 72: 4551-4561, 2012.

32. Okawa Y, Hideshima T, Steed P, Vallet S, Hall S, Huang K, Rice J, Barabasz A, Foley B, Ikeda H, et al: SNX-2112, a selective Hsp90 inhibitor, potently inhibits tumor cell growth, angiogenesis, and osteoclastogenesis in multiple myeloma and other hematologic tumors by abrogating signaling via Akt and ERK. Blood 113 846-855, 2009

33. Eilard MS, Andersson M, Naredi P, Geronymakis C, Lindnér P, Cahlin C, Bennet W and Rizell M: A prospective clinical trial on sorafenib treatment of hepatocellular carcinoma before liver transplantation. BMC Cancer 19: 568, 2019.

34. Kim JB, Lee M, Park SY, Lee S, Kim HR, Lee HS, Yoon JH and Kim YJ: Sorafenib inhibits cancer side population cells by targeting cJun Nterminal kinase signaling. Mol Med Rep 12: $8247-8252,2015$

35. Ha TY, Hwang S, Hong HN, Choi YI, Yoon SY, Won YJ, Song GW, Kim N, Tak E and Ryoo BY: Synergistic effect of sorafenib and vitamin $\mathrm{K}$ on suppression of hepatocellular carcinoma cell migration and metastasis. Anticancer Res 35: 1985-1995, 2015

36. Yi P, Higa A, Taouji S, Bexiga MG, Marza E, Arma D, Castain C, Le Bail B, Simpson JC, Rosenbaum J, et al: Sorafenib-mediated targeting of the $\mathrm{AAA}^{+}$ATPase $\mathrm{p} 97 / \mathrm{VCP}$ leads to disruption of the secretory pathway, endoplasmic reticulum stress, and hepatocellular cancer cell death. Mol Cancer Ther 11: 2610-2620, 2012.

37. Sauzay C, Louandre C, Bodeau S, Anglade F, Godin C, Saidak Z, Fontaine JX, Usureau C, Martin N, Molinie R, et al: Protein biosynthesis, a target of sorafenib, interferes with the unfolded protein response (UPR) and ferroptosis in hepatocellular carcinoma cells. Oncotarget 9: 8400-8414, 2018.

38. Vaishampayan UN, Burger AM, Sausville EA, Heilbrun LK, Li J, Horiba MN, Egorin MJ, Ivy P, Pacey S and Lorusso PM: Safety, efficacy, pharmacokinetics, and pharmacodynamics of the combination of sorafenib and tanespimycin. Clin Cancer 16 : 3795-3804, 2010

39. Booth L, Shuch B, Albers T, Roberts JL, Tavallai M, Proniuk S, Zukiwski A, Wang D, Chen CS, Bottaro D, et al: Multi-kinase inhibitors can associate with heat shock proteins through their NH2-termini by which they suppress chaperone function. Oncotarget 7: 12975-12996, 2016.

40. Barta TE, Veal JM, Rice JW, Partridge JM, Fadden RP, Ma W, Jenks M, Geng L, Hanson GJ, Huang KH, et al: Discovery of benzamide tetrahydro-4H-carbazol-4-ones as novel small molecule inhibitors of Hsp90. Bioorg Med Chem Lett 18: 3517-3521, 2008.

41. Xu WW, Li B, Guan XY, Chung SK, Wang Y, Yip YL, Law SY, Chan KT, Lee NP, Chan KW, et al: Cancer cell-secreted IGF2 instigates fibroblasts and bone marrow-derived vascular progenitor cells to promote cancer progression. Nat Commun 8: 14399, 2017.

42. Wang J, Lian Y, Gu Y, Wang H, Gu L, Huang Y, Zhou L and Huang Y: Synergistic effect of farnesyl transferase inhibitor lonafarnib combined with chemotherapeutic agents against the growth of hepatocellular carcinoma cells. Oncotarget 8 105047-105060, 2017.

43. Nishanth RP, Ramakrishna BS, Jyotsna RG, Roy KR, Reddy GV Reddy PK and Reddanna P: C-Phycocyanin inhibits MDR1 through reactive oxygen species and cyclooxygenase-2 mediated pathways in human hepatocellular carcinoma cell line. Eur J Pharmacol 649: 74-83, 2010

44. Kuzuya T, Ishigami M, Ito T, Ishizu Y, Honda T, Ishikawa T, Hirooka Y and Fujishiro M: Clinical characteristics and outcomes of candidates for second-line therapy, including regorafenib and ramucirumab, for advanced hepatocellular carcinoma afte sorafenib treatment. Hepatol Res 49: 1054-1065, 2019.

45. Yurdacan B, Egeli U, Guney Eskiler G, Eryilmaz IE, Cecener G and Tunca B: Investigation of new treatment option for hepatocellular carcinoma: A combination of sorafenib with usnic acid. J Pharmacy Pharmacol 71: 1119-1132, 2019.
46. Cheng AL, Guan Z, Chen Z, Tsao CJ, Qin S, Kim JS, Yang TS, Tak WY, Pan H, Yu S, et al: Efficacy and safety of sorafenib in patients with advanced hepatocellular carcinoma according to baseline status: Subset analyses of the phase III Sorafenib Asia-Pacific trial. Eur J Cancer 48: 1452-1465, 2012.

47. Cheng AL, Kang YK, Chen Z, Tsao CJ, Qin S, Kim JS, Luo R, Feng J, Ye S, Yang TS, et al: Efficacy and safety of sorafenib in patients in the Asia-Pacific region with advanced hepatocellular carcinoma: A phase III randomised, double-blind, placebo-controlled trial. Lancet Oncol 10: 25-34, 2009.

48. Morisaki T, Umebayashi M, Kiyota A, Koya N, Tanaka H, Onishi $\mathrm{H}$ and Katano M: Combining celecoxib with sorafenib synergistically inhibits hepatocellular carcinoma cells in vitro. Anticancer Res 33: 1387-1395, 2013.

49. Ceballos MP, Rigalli JP, Cere LI, Semeniuk M, Catania VA and Ruiz ML: ABC Transporters: Regulation and association with multidrug resistance in hepatocellular carcinoma and colorectal carcinoma. Curr Med Chemistry 26: 1224-1250, 2019.

50. Wilhelm S, Carter C, Lynch M, Lowinger T, Dumas J, Smith RA, Schwartz B, Simantov R and Kelley S: Discovery and development of sorafenib: A multikinase inhibitor for treating cancer. Nat Rev Drug Discov 5: 835-844, 2006.

51. Meyer A, Cygan P, Tolzien K, Galvez AG, Bitran JD, Lestingi TM and Nabhan C: Role of sorafenib in overcoming resistance of chemotherapy-failure castration-resistant prostate cancer. Clin Genitourin Cancer 12: 100-105, 2014.

52. Decker T, Overkamp F, Rösel S, Nusch A, Göhler T, Indorf M, Sahlmann J and Trarbach T: A randomized phase II study of paclitaxel alone versus paclitaxel plus sorafenib in second- and third-line treatment of patients with HER2-negative metastatic breast cancer (PASO). BMC Cancer 17: 499, 2017.

53. Gongora C: Sorafenib inhibits ABCG2 and overcomes irinotecan resistance-response. Mol Cancer Ther 13: 764, 2014

54. Sun Y, Zhang J, Zhou J, Huang Z, Hu H, Qiao M, Zhao X and Chen D: Synergistic effect of cucurbitacin B in combination with curcumin via enhancing apoptosis induction and reversing multidrug resistance in human hepatoma cells. Eur J Pharmacol 768: 28-40, 2015.

55. Kim JE, Kim SG, Goo JS, Park DJ, Lee YJ, Hwang IS, Lee HR, Choi SI, Lee YJ, Oh CH, et al: The $\alpha$-iso-cubebenol compound isolated from Schisandra chinensis induces p53-independent pathway-mediated apoptosis in hepatocellular carcinoma cells. Oncol Rep 28: 1103-1109, 2012.

56. Subramaniam A, Shanmugam MK, Perumal E, Li F, Nachiyappan A, Dai X, Swamy SN, Ahn KS, Kumar AP, Tan BK, et al: Potential role of signal transducer and activator of transcription (STAT)3 signaling pathway in inflammation, survival, proliferation and invasion of hepatocellular carcinoma. Biochim Biophys Acta 1835: 46-60, 2013.

57. Schindler $\mathrm{C}$ and Darnell JE Jr: Transcriptional responses to polypeptide ligands: The JAK-STAT pathway. Ann Rev Biochem 64: 621-651, 1995.

58. Zeidler MP, Bach EA and Perrimon N: The roles of the drosophila JAK/STAT pathway. Oncogene 19: 2598-2606, 2000.

59. Hirano T, Ishihara K and Hibi M: Roles of STAT3 in mediating the cell growth, differentiation and survival signals relayed through the IL-6 family of cytokine receptors. Oncogene 19: 2548-2556, 2000.

60. Yoshikawa H, Matsubara K, Qian GS, Jackson P, Groopman JD, Manning JE, Harris CC and Herman JG: SOCS-1, a negative regulator of the JAK/STAT pathway, is silenced by methylation in human hepatocellular carcinoma and shows growth-suppression activity. Nat Genet 28: 29-35, 2001

61. Niwa Y, Kanda H, Shikauchi Y, Saiura A, Matsubara K, Kitagawa T, Yamamoto J, Kubo T and Yoshikawa H: Methylation silencing of SOCS-3 promotes cell growth and migration by enhancing JAK/STAT and FAK signalings in human hepatocellular carcinoma. Oncogene 24: 6406-6417, 2005.

62. Feng DY, Zheng H, Tan Y and Cheng RX: Effect of phosphorylation of MAPK and Stat 3 and expression of c-fos and c-jun proteins on hepatocarcinogenesis and their clinical significance. World J Gastroenterol 7: 33-36, 2001.

63. Lee $\mathrm{C}$ and Cheung ST: STAT3: An emerging therapeutic target for hepatocellular Carcinoma. Cancers (Basel) 11: 1646, 2019.

This work is licensed under a Creative Commons

Attribution-NonCommercial-NoDerivatives 4.0 International (CC BY-NC-ND 4.0) License. 